\title{
Correlation between Chemical Durability Behaviour and Structural Approach of the Vitreous Part of the System $55 \mathrm{P}_{2} \mathrm{O}_{5}-2 \mathrm{Cr}_{2} \mathrm{O}_{3}-(43-\mathrm{x}) \mathrm{Na}_{2} \mathrm{O}-\mathrm{xPbO}$
}

\author{
Nadia Beloued ${ }^{1}$, Zineb Chabbou1 ${ }^{1}$, Said Aqdim ${ }^{1,2^{*}}$ \\ ${ }^{1}$ Laboratoire de Génie des Matériaux pour Environnement et Valorisation, Faculté des Sciences, Université \\ Hassan II Ain Chock, Casablanca, Morocco \\ ${ }^{2}$ Laboratoire de Chimie Minérale, Département de Chimie, Faculté des Sciences, Université Hassan II Ain Chock, \\ Casablanca, Morocco \\ Email: "said_aq@yahoo.fr
}

Received 4 April 2016; accepted 21 June 2016; published 24 June 2016

Copyright (C) 2016 by authors and Scientific Research Publishing Inc.

This work is licensed under the Creative Commons Attribution International License (CC BY). http://creativecommons.org/licenses/by/4.0/

(c) (i) Open Access

\begin{abstract}
Various characterisation techniques were used to study the composition of the glass series 55$\mathrm{P}_{2} \mathrm{O}_{5}-2 \mathrm{Cr}_{2} \mathrm{O}_{3}-(43-x) \mathrm{Na}_{2} \mathrm{O}$-xPbO (with $8 \leq \mathrm{x} \leq 38$; mole \%) in terms of chemical durability, IR spectroscopy and scanning electron microscopy (SEM). The change in the dissolution rate as a function of time when the studied glasses were kept submerged in distilled water at $90^{\circ} \mathrm{C}$ for 20 days showed an improvement in the chemical durability when $\mathrm{Na}_{2} \mathrm{O}$ content was substituted to $\mathrm{PbO}$ content. IR spectroscopy revealed a structural change from ultraphosphate groups to pyrophosphate, orthophosphate and probably ring metaphosphate groups. SEM revealed the existence of two phases: a vitreous phase and a crystalline phase. The presence of $\mathrm{Cr}_{2} \mathrm{O}_{3}$, even in small amounts, seems to play an important role in the formation of crystallites in the glass network. The improved chemical durability is attributed to the replacement of the easily hydrated Na-O-P and P-O-P bonds by covalent and resistant $\mathrm{Pb}-\mathrm{O}-\mathrm{P}$ bands. Both the increase in $\mathrm{PbO}$ content and in the $\mathrm{Pb}+\mathrm{Cr} / \mathrm{P}$ ratio causes an increase in the number of covalent $\mathrm{Pb}-\mathrm{O}-\mathrm{P}$ and $\mathrm{Cr}-\mathrm{O}-\mathrm{P}$ bonds, making the glass structure more rigid. The increase of the covalent $\mathrm{Pb}-\mathrm{O}-\mathrm{P}$ bands leads to a clear evolution of the structure and chemical resistance, caused by grain-boundary resistance as a result of glass crystallisation. The IR spectra indicate that the increase in $\mathrm{PbO}$ content favours the formation of isolated $\mathrm{PO}_{4}^{3-}$ orthophosphate groups at the expense of pyrophosphate groups. The radical change in the structure from ultraphosphate groups to pyrophosphate and orthophosphate groups seems to be the cause of the formation of crystallites. The existence of crystallites in these glasses results in a marked improvement in their chemical durability. However, when the crystallites exceed a certain
\end{abstract}

${ }^{*}$ Corresponding author.

How to cite this paper: Beloued, N., Chabbou, Z. and Aqdim, S. (2016) Correlation between Chemical Durability Behaviour and Structural Approach of the Vitreous Part of the System $55 \mathrm{P}_{2} \mathrm{O}_{5}-2 \mathrm{Cr}_{2} \mathrm{O}_{3}-(43-\mathrm{x}) \mathrm{Na}{ }_{2} \mathrm{O}-\mathrm{xPbO}$. Advances in Materials Physics and Chemistry, 6, 149-156. http://dx.doi.org/10.4236/ampc.2016.66016 
limit, the equilibrium between the glass bath and these crystallites is no longer maintained; we notice, once, a decrease in the chemical durability.

\author{
Keywords
}

\author{
Phosphate Glasses, Chemical Durability, IR, SEM
}

\title{
1. Introduction
}

Phosphate glasses have been investigated principally because of their relatively low processing temperatures $\left(1000^{\circ} \mathrm{C}-1200^{\circ} \mathrm{C}\right)$ compared with borosilicate glasses $\left(1200^{\circ} \mathrm{C}-1500^{\circ} \mathrm{C}\right)$ and their relatively low softening temperature and liquid viscosity. Iron phosphate glasses, in particular, have shown the potential to vitrify many nuclear wastes that undergo completely unsuitable or poorly suitable vitrification in borosilicate glasses, such as heavy metals, phosphates, sulphates and chromium oxides that are insoluble in or chemically incompatible with borosilicate glass. The main problem in the use of phosphate glasses is their relatively low chemical resistance, which leads to relatively high leaching rates when they are exposed to humid environments [1] [2]. During the 1990s, an enhancement in chemical resistance was observed when iron and lead were used in the glass formulation [2]-[4]. This improvement resulted in reduced corrosion rates in aqueous environments and allowed the immobilisation of medium and high-activity radioactive wastes [4]-[9]. In this work, our aim is to contribute to the immobilisation of nuclear waste in a phosphate glass matrix, as a route to help in the prevention of environmental contamination. The study of the chemical durability and structural change along the series of phosphate glasses $55 \mathrm{P}_{2} \mathrm{O}_{5}-2 \mathrm{Cr}_{2} \mathrm{O}_{3}-(43-\mathrm{x}) \mathrm{Na}_{2} \mathrm{O}-\mathrm{xPbO}$ (with $8 \leq \mathrm{x} \leq 38 \mathrm{~mol} \%$ ) shows that an increase in $\mathrm{PbO}$ content in the glass network leads to an improvement in chemical durability which is explained by a radical change in the structure. This change is due to the increase of $\mathrm{Pb}-\mathrm{O}-\mathrm{P}$ covalent bonds in the glass. SEM micrographs show the presence of both a glass phase and a crystalline phase. The presence of both $\mathrm{Pb}-\mathrm{O}-\mathrm{P}$ and $\mathrm{Cr}-\mathrm{O}-\mathrm{P}$ covalent bands suggests that the formation of an increasing number of crystallites in the glass is the main cause of the increase in chemical durability. The IR spectra show a radical change in the structure from ultraphosphate groups to orthophosphate groups.

\section{Experimental Procedures}

The synthesis of chromium lead phosphate glasses of composition $55 \mathrm{P}_{2} \mathrm{O}_{5}-2 \mathrm{Cr}_{2} \mathrm{O}_{3}$ (43-x) $\mathrm{Na}_{2} \mathrm{O}-\mathrm{xPbO}$ (with $8 \leq$ $\mathrm{x} \leq 38 \mathrm{~mol} \%$ ) was carried out using direct fusion mixtures of $\left(\mathrm{NH}_{4}\right)_{2} \mathrm{HPO}_{4}, \mathrm{Na}_{2} \mathrm{CO}_{3}, \mathrm{Cr}_{2} \mathrm{O}_{3}$ and $\mathrm{PbO}$ in suitable proportions. The reactants were finely ground and then introduced into a porcelain crucible. They were heated initially to $300^{\circ} \mathrm{C}$ for 1 hour then kept at $600^{\circ} \mathrm{C}$ for 1 hour to complete their decomposition. The reaction mixture was then heated to $1060^{\circ} \mathrm{C}-1100^{\circ} \mathrm{C}$ for 20 minutes. The resulting homogeneous liquid was poured into an aluminium plate, preheated to $200^{\circ} \mathrm{C}$ to avoid thermal shock. In our experiments pellets about $1 \mathrm{~cm}$ in diameter and 2 to $3 \mathrm{~mm}$ thick were obtained. The chemical resistance of these glasses was evaluated from the sample weight loss. The samples were polished with carbon silica sandpaper (with CSI of sufficiently high level), cleaned with acetone and immersed in Pyrex beakers containing $100 \mathrm{ml}$ of distilled water and carried to $90^{\circ} \mathrm{C}$. The sample surface must be constantly submerged in distilled water for 20 consecutive days. The infrared spectra of the studied phosphate glasses were determined in the region between 1600 and $400 \mathrm{~cm}^{-1}$ with a resolution of $2 \mathrm{~cm}^{-1}$. The samples were finely ground and mixed with $\mathrm{KBr}$ (potassium bromide), which is transparent in the infrared and serves as a template. The ratio of the matter/ $\mathrm{KBr}$ in the pellets was $10 \%$ to $90 \%$ by weight. Infrared spectroscopic analysis of the materials was performed on a Fourier form Vertex 70 spectrometer and recorded on a DTGS detector (deuterium triglycine sulphate). The microstructure of the glass samples was characterised using a scanning electron microscope (SEM) equipped with a complete system microanalyser (EDX-EDAX).

\section{Results and Discussion}

\subsection{Chemical Durability}

The chemical durability of the glass series $55 \mathrm{P}_{2} \mathrm{O}_{5}-2 \mathrm{Cr}_{2} \mathrm{O}_{3}-(43-\mathrm{x}) \mathrm{Na}_{2} \mathrm{O}-\mathrm{xPbO}$ (with $8 \leq \mathrm{x} \leq 38$ mol \%) was de- 
termined by measuring the dissolution rate $\left(D_{R}\right)$ of glasses immersed for 20 consecutive days in $100 \mathrm{ml}$ of distilled water heated to $90^{\circ} \mathrm{C}$ [6] [10]. The dissolution rate is defined as the loss of weight of the glass expressed in $\mathrm{g} \cdot \mathrm{cm}^{-2} \cdot \mathrm{min}^{-1}$. The $\mathrm{D}_{\mathrm{R}}$ and $\mathrm{pH}$ values are shown in Table 1 . In Figure 1 we see a gradual improvement in the chemical durability of glasses from $3.82 \times 10^{-7}$ to $3.47 \times 10^{-9}\left(\mathrm{~g} / \mathrm{cm}^{2} \cdot \mathrm{min}\right)$ when the $\mathrm{PbO}$ content varies at the expense of $\mathrm{Na}_{2} \mathrm{O}$ from 8 to 28 mole \% respectively. However, we noted a decrease in the chemical durability when the $\mathrm{PbO}$ content ranges from 28 to $38 \mathrm{~mol} \%$. Figure 2 shows a slight increase in the $\mathrm{pH}$ when the $\mathrm{PbO}$ content increases. However, we note that the $\mathrm{pH}$ decreases slightly when $\mathrm{PbO}$ content ranges from 28 to 38 mol \%. This appears to be explained by the presence of phosphoric polyacid or phosphoric acid in the solution caused by a small degradation of S4 glass, which also results in a slight decrease in the chemical durability.

\subsection{Infrared Spectra}

IR spectra of the glass series $55 \mathrm{P}_{2} \mathrm{O}_{5}-2 \mathrm{Cr}_{2} \mathrm{O}_{3}(43-\mathrm{x}) \mathrm{Na}_{2} \mathrm{O}-\mathrm{xPbO}(8 \leq 8 \leq 38$; mol \%) are shown in Figure 3 . All vibration bands of treated phosphate glasses are shown in the frequency range between 390 and $1590 \mathrm{~cm}^{-1}$. The band at $500-510 \mathrm{~cm}^{-1}$ is assigned to the deformation of the skeleton $\delta_{\text {ske }}(\mathrm{P}-\mathrm{O}-\mathrm{P})$ [11]. The band at $730-750$ $\mathrm{cm}^{-1}$ is assigned to the symmetric stretching $v_{\text {sym }}$ (P-O-P) phosphorus bridge tetrahedral [6], while the bands at $870-900$ and $975-980 \mathrm{~cm}^{-1}$ are assigned respectively to the vibration of asymmetric $v_{\text {asym }}(\mathrm{P}-\mathrm{O}-\mathrm{P})$ and $v_{\mathrm{s}}$ $\mathrm{PO}_{4}^{3-}$ due to non-bridging oxygen atoms [5] [12] [13]. The band at about 1069 to $1103 \mathrm{~cm}^{-1}$ is attributed to the stretching of $v_{\text {sym }}\left(\mathrm{PO}_{3}\right) / v_{\text {asym }}\left(\mathrm{PO}_{3}\right)$ while the band from 1222 to $1225 \mathrm{~cm}^{-1}$ is assigned to the stretching of $v_{\text {asym }}$ $\left(\mathrm{PO}_{2}\right)$ [5] [6]. With increasing values of $\mathrm{x}$, the intensity of the bands characteristic of pyrophosphate groups tends to decrease while the bands typical of orthophosphate groups tend to increase and dominate as $\mathrm{PbO}$ content increases relative to $\mathrm{Na}_{2} \mathrm{O}$ content. This phenomenon becomes apparent in the spectrum of the composition

Table 1. Glasses composition in mol \% and selected properties of sodium lead chromium phosphate glasses.

\begin{tabular}{|c|c|c|c|c|c|c|c|}
\hline \multirow{2}{*}{$\begin{array}{l}\text { Glass } \\
\text { Sample }\end{array}$} & \multicolumn{4}{|c|}{ Starting mixtures oxide mol \% } & \multirow{2}{*}{ Ratio [O/P] } & \multirow{2}{*}{$D_{R}\left(g / \mathrm{cm}^{2} / \mathrm{min}\right)$} & \multirow{2}{*}{$\mathbf{p H}$} \\
\hline & PbO & $\mathrm{Na}_{2} \mathrm{O}$ & $\mathrm{Cr}_{2} \mathrm{O}_{3}$ & $\mathbf{P}_{2} \mathbf{O}_{5}$ & & & \\
\hline $\mathrm{S}_{1}$ & 8 & 35 & 2 & 55 & \multirow{4}{*}{2.95} & $(3.81 \pm 0.20) \times 10^{-7}$ & $6.47 \pm 0.50$ \\
\hline $\mathrm{S}_{2}$ & 18 & 25 & 2 & 55 & & $(3.50 \pm 0.20) \times 10^{-8}$ & $6.80 \pm 0.50$ \\
\hline $\mathrm{S}_{3}$ & 28 & 15 & 2 & 55 & & $(1.74 \pm 0.20) \times 10^{-9}$ & $6.70 \pm 0.50$ \\
\hline $\mathrm{S}_{4}$ & 38 & 5 & 2 & 55 & & $(3.50 \pm 0.20) \times 10^{-9}$ & $6.30 \pm 0.50$ \\
\hline
\end{tabular}

\section{$55 \mathrm{P}_{2} \mathrm{O}_{5}-2 \mathrm{Cr}_{2} \mathrm{O}_{3}-(43-x) \mathrm{Na}_{2} \mathrm{O}-\mathrm{xPbO}$}

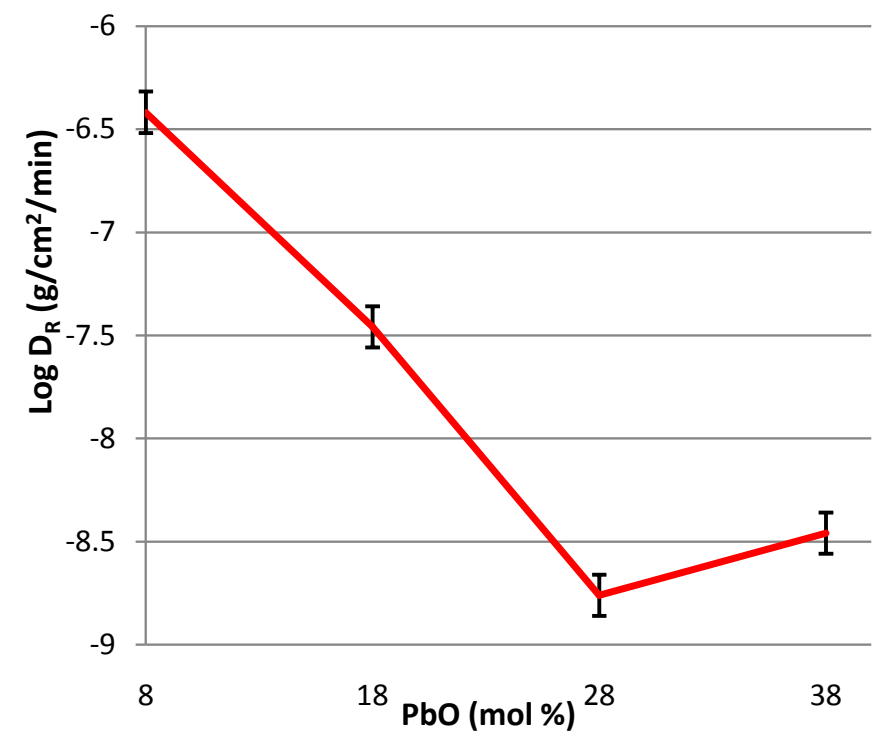

Figure 1. Dissolution rates $\left(\mathrm{D}_{\mathrm{R}}\right)$ of the glass series $55 \mathrm{P}_{2} \mathrm{O}_{5}$ $2 \mathrm{Cr}_{2} \mathrm{O}_{3}-(43-\mathrm{x}) \mathrm{Na}_{2} \mathrm{O}-\mathrm{xPbO}$ versus $\mathrm{PbO}$ (mol\%). 


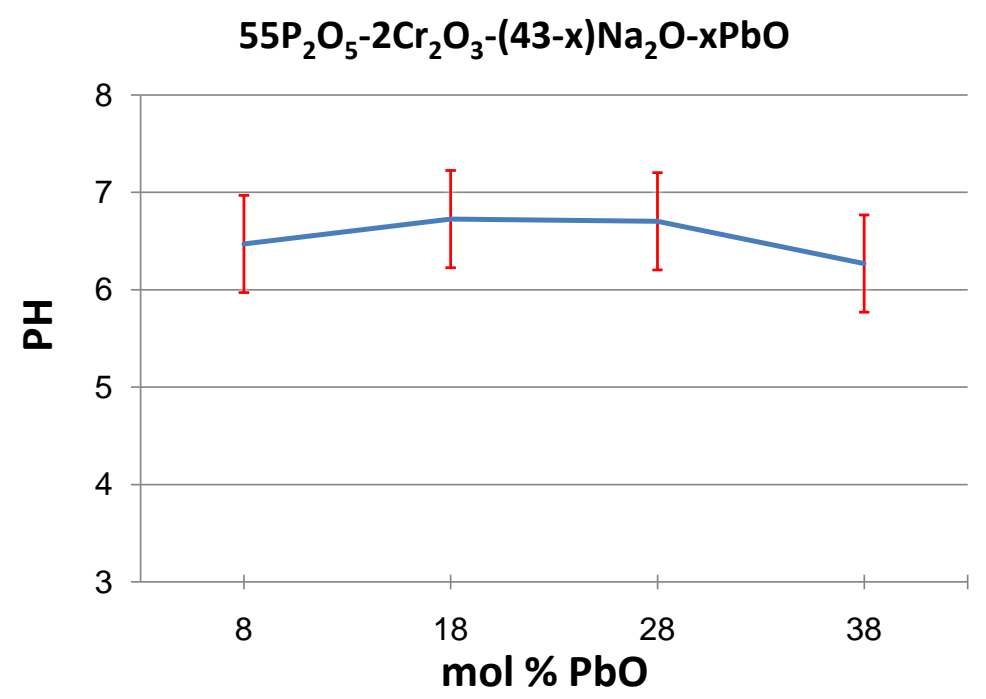

Figure 2. The $\mathrm{pH}$ values of the solution of sodium-lead chromium phosphate glasses were, immersed at $90^{\circ} \mathrm{C}$ for 20 days versus $\mathrm{PbO}$ (mol \%).

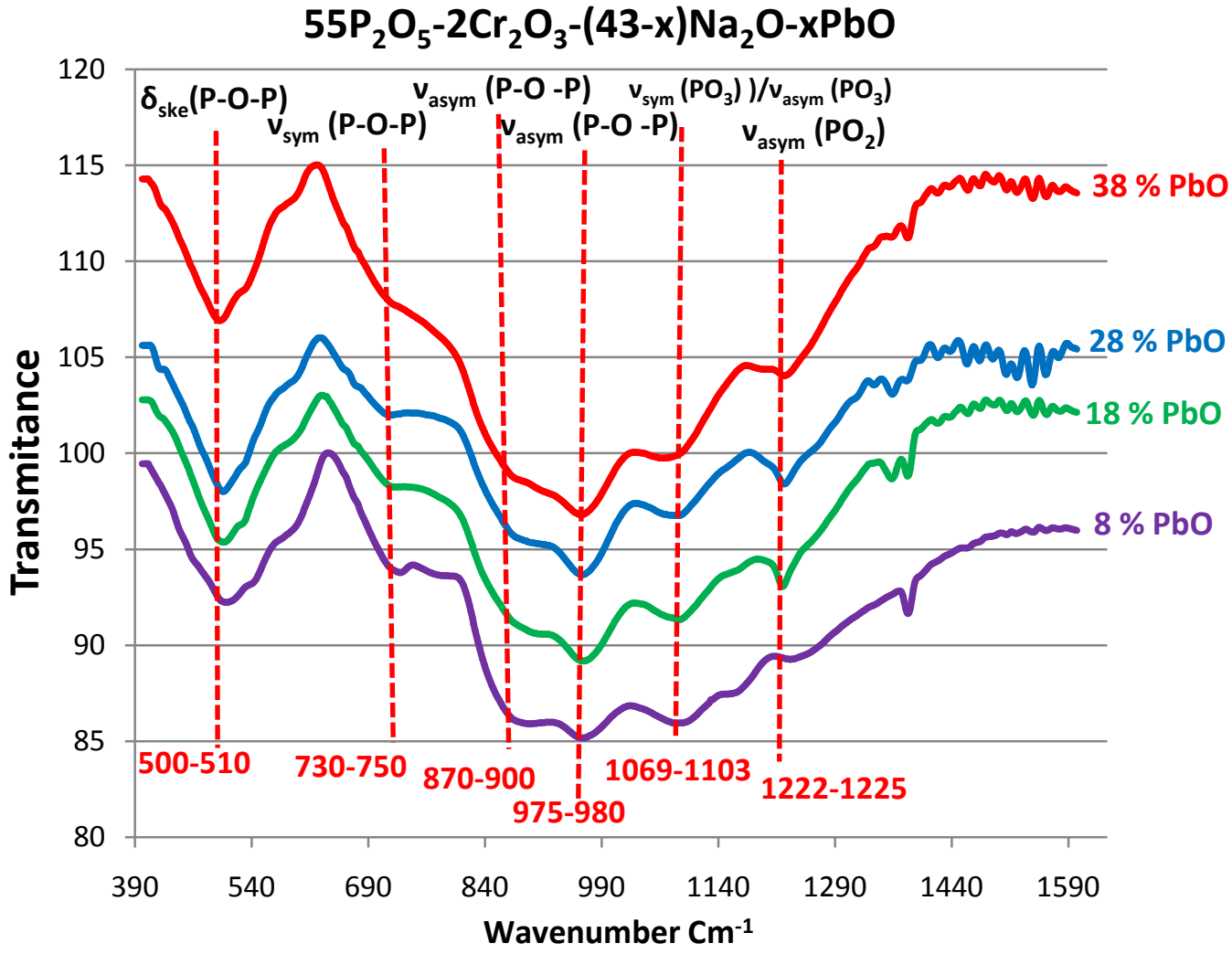

Figure 3. IR spectra of the series $55 \mathrm{P}_{2} \mathrm{O}_{5}-2 \mathrm{Cr}_{2} \mathrm{O}_{3}-(43-\mathrm{x}) \mathrm{Na}_{2} \mathrm{O}-\mathrm{xPbO} ; \mathrm{x}=8,18,28$ and 38.

S4 where vibration bands at $730-750 \mathrm{~cm}^{-1}$ and $840-900 \mathrm{~cm}^{-1}$ become a simple shoulder while the band at 975 - $980 \mathrm{~cm}^{-1}$ becomes wider and more intense [3] [5] [14] [15]. On the other hand, Figure 4 and Table 2 show that the studied glasses are located in the field of ultra-phosphate chains. As we expected that the structural change would be schematically the same as that found in the ternary diagram (Figure 4), we Remarque that it doesn't the case. This is seems to due to the physical and chemical properties of the intermediate oxide that participates in the glass formation (melting temperature, rate of $\mathrm{Pb}+\mathrm{Cr} / \mathrm{P}$...) [2]. 


\subsection{SEM Analysis}

The SEM micrograph (Figure 5) shows the existence of two phases, a vitreous phase and a crystalline phase [5] [15]. It also indicates the formation of crystalline phase agglomerates of various sizes, ranging from some microns to several tens of microns as seen from Figure 5(a) to Figure 5(c) attributed respectively to the samples $\mathrm{S} 1, \mathrm{~S} 3$ and S4. This probably explains the structural change towards more short chains as the rate of $\mathrm{PbO}$ increases in the glass network. On the other hand the micrographs of the samples after attack by distilled water at $90^{\circ} \mathrm{C}$ for 20 consecutive days (Figure 5(d) to Figure 5(f)), attributed respectively to the samples S1, S3 and S4, indicate these glasses are intact, and deposits in the bottom of the containers bottom are not visible to the naked eye.

\subsection{Discussion}

In our study, we prepared a glass series with different percentages of phosphate oxides: $\mathrm{PbO}, \mathrm{Na}_{2} \mathrm{O}, \mathrm{Cr}_{2} \mathrm{O}_{3}$ and $\mathrm{P}_{2} \mathrm{O}_{5}$ were used as the basic constituents. In this series we substituted the $\mathrm{Na}_{2} \mathrm{O}$ oxide with $\mathrm{PbO}$ oxide while keeping the percentage of $\mathrm{P}_{2} \mathrm{O}_{5}$ and $\mathrm{Cr}_{2} \mathrm{O}_{3}$ oxides constants. Both the presence of $\mathrm{Cr}_{2} \mathrm{O}_{3}$ and the substitution of $\mathrm{Na}_{2} \mathrm{O}$ by $\mathrm{PbO}$ in the glass network lead to a considerable improvement in the chemical durability [3] [5] [15]. The improved chemical durability is attributed to the replacement of the easily hydrated Na-O-P and P-O-P bonds by covalent and resistant $\mathrm{Pb}-\mathrm{O}-\mathrm{P}$ bands. Both the increase in $\mathrm{PbO}$ content and in the $\mathrm{Pb}+\mathrm{Cr} / \mathrm{P}$ ratio cause an increase in the number of covalent $\mathrm{Pb}-\mathrm{O}-\mathrm{P}$ and $\mathrm{Cr}-\mathrm{O}-\mathrm{P}$ bands and make the glass structure more rigid. This represents a clear evolution in the structure and chemical resistance, caused by grain-boundary resistance as result of glass crystallisation [16]-[20]. On the other hand, IR spectra indicated that both the presence of $\mathrm{Cr}_{2} \mathrm{O}_{3}$ and increasing $\mathrm{PbO}$ content from 8 to $38 \mathrm{~mol} \%$ at the expense of $\mathrm{Na}_{2} \mathrm{O}$ promote depolymerisation of the glass network by creating short chain pyrophosphates, orthophosphates and probably ring metaphosphate chains. Furthermore a large band attributed to the stretching of vs $\mathrm{PO}_{4}^{3-}$ [15] appears at $975-980 \mathrm{~cm}^{-1}$, to the detriment of the band at $870-900 \mathrm{~cm}^{-1}$, which becomes a simple shoulder when the $\mathrm{PbO}$ content reach $38 \mathrm{~mol} \%$. This

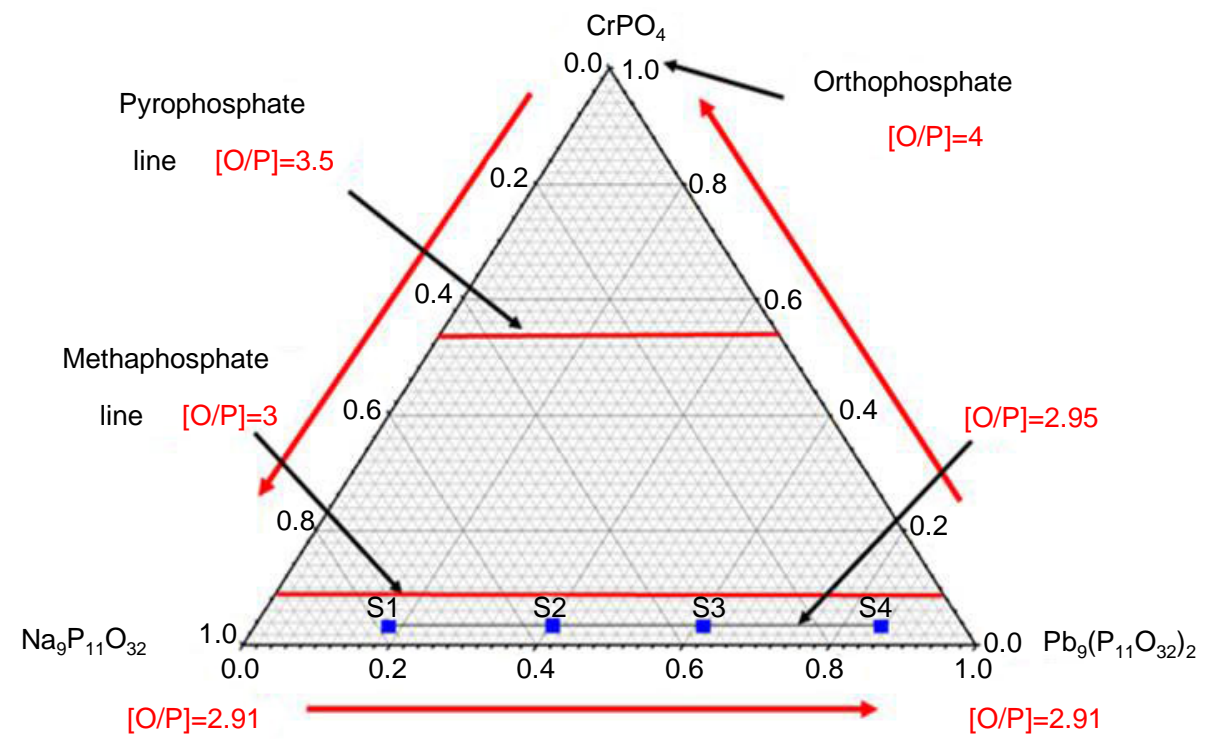

Figure 4. Localization of the investigated glass compositions in the ternary diagram.

Table 2. Glass composition expressed as in terms of ternary and quaternary systems.

\begin{tabular}{ccc}
\hline Glass samples & Chemical composition & Composition of glasses in the ternary diagram \\
\hline $\mathrm{S}_{1}$ & $35 \mathrm{Na}_{2} \mathrm{O} \cdot 8 \mathrm{PbO} \cdot 2 \mathrm{Cr}_{2} \mathrm{O}_{3} \cdot 55 \mathrm{P}_{2} \mathrm{O}_{5}$ & $0.044\left(\mathrm{Cr}_{2} \mathrm{O}_{3}-\mathrm{P}_{2} \mathrm{O}_{5}\right) \cdot 0.778\left(\mathrm{Na}_{2} \mathrm{O}-\mathrm{P}_{2} \mathrm{O}_{5}\right) \cdot 0.178\left(\mathrm{PbOP}_{2} \mathrm{O}_{5}\right)$ \\
$\mathrm{S}_{2}$ & $25 \mathrm{Na}_{2} \mathrm{O} \cdot 18 \mathrm{PbO} \cdot 2 \mathrm{Cr}_{2} \mathrm{O}_{3} \cdot 55 \mathrm{P}_{2} \mathrm{O}_{5}$ & $0.044\left(\mathrm{Cr}_{2} \mathrm{O}_{3}-\mathrm{P}_{2} \mathrm{O}_{5}\right) \cdot 0.556\left(\mathrm{Na}_{2} \mathrm{O}-\mathrm{P}_{2} \mathrm{O}_{5}\right) \cdot 0.4\left(\mathrm{PbO}-\mathrm{P}_{2} \mathrm{O}_{5}\right)$ \\
$\mathrm{S}_{3}$ & $15 \mathrm{Na}_{2} \mathrm{O} \cdot 28 \mathrm{PbO} \cdot 2 \mathrm{Cr}_{2} \mathrm{O}_{3} \cdot 55 \mathrm{P}_{2} \mathrm{O}_{5}$ & $0.044\left(\mathrm{Cr}_{2} \mathrm{O}_{3}-\mathrm{P}_{2} \mathrm{O}_{5}\right) \cdot 0.333\left(\mathrm{Na}_{2} \mathrm{O}-\mathrm{P}_{2} \mathrm{O}_{5}\right) \cdot 0.622\left(\mathrm{PbO}_{2} \mathrm{P}_{2} \mathrm{O}_{5}\right)$ \\
$\mathrm{S}_{4}$ & $5 \mathrm{Na}_{2} \mathrm{O} \cdot 38 \mathrm{PbO} \cdot 2 \mathrm{Cr}_{2} \mathrm{O}_{3} \cdot 55 \mathrm{P}_{2} \mathrm{O}_{5}$ & $0.044\left(\mathrm{Cr}_{2} \mathrm{O}_{3}-\mathrm{P}_{2} \mathrm{O}_{5}\right) \cdot 0.111\left(\mathrm{Na}_{2} \mathrm{O}-\mathrm{P}_{2} \mathrm{O}_{5}\right) \cdot 0.845\left(\mathrm{PbO}-\mathrm{P}_{2} \mathrm{O}_{5}\right)$ \\
\hline
\end{tabular}



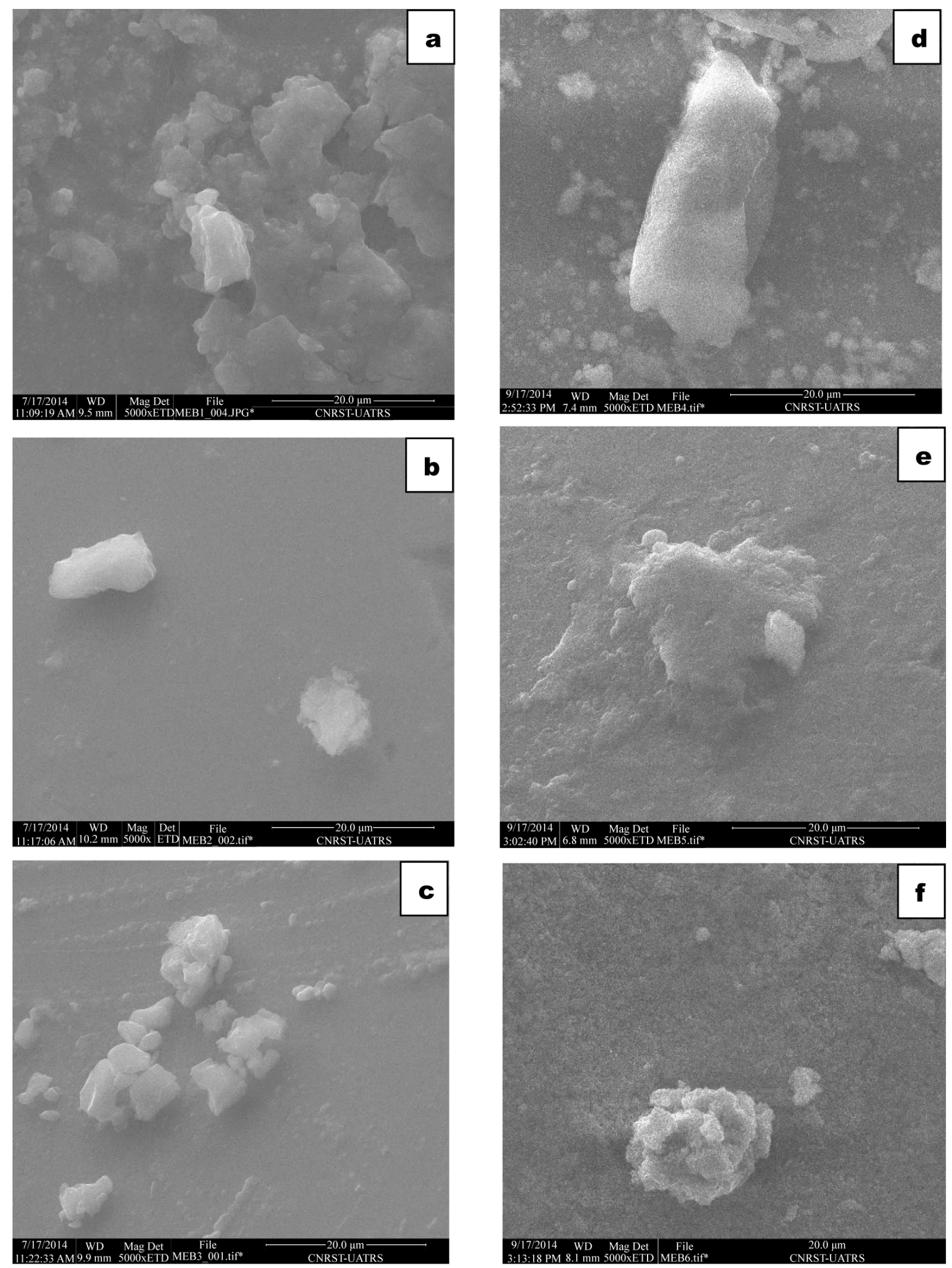

Figure 5. SEM micrograph showing the visual structure of the samples S1 (a), S3 (b), S4 (c) before the aqueous attack and of the samples S1 (d), S3 (e), S4 (f) after the aqueous attack. 
indicates the predominance of isolated orthophosphategroups $\left(\mathrm{Q}^{0}\right)$. The decrease in chemical durability beyond $28 \mathrm{~mol} \% \mathrm{PbO}$ seems to be explained by the increase of crystallites in the glass, which contain the majority of the isolated orthophosphate phases $\left(Q^{0}\right)$. According to the IR spectra, the $\left(Q^{0}\right)$ groups increase at the expense of both pyrophosphate groups $\left(\mathrm{Q}^{1}\right)$ and metaphosphates $\left(\mathrm{Q}^{2}\right)$ [12]. Generally an increase in crystallites in glasses causes an increase in chemical durability. This paradox can be explained by the fact that when the crystallites that dominate the glass belong to orthophosphate crystal phases $(\mathrm{O} / \mathrm{P}=4)$, this indicates that we are near the border between the glass and the crystal [2]. In this case, the chemical durability becomes relatively low due to the break of the glass structure, probably caused by a lack of equilibrium between the glass phase and the crystallites formed. The SEM micrographs of samples S1, S3 and S4 are consistent with this theory, with this theory that probably explains the decrease in crystallites size when the PbO content increases from S1 to S4. Therefore we can predict a depolymerisation of the largest phosphate network to isolated short chains of the orthophosphate $\left(\mathrm{Q}^{0}\right)$ type.

\section{Conclusion}

The influence of $\mathrm{PbO}$ on the glass forming characteristics and properties of $55 \mathrm{P}_{2} \mathrm{O}_{5}-2 \mathrm{Cr}_{2} \mathrm{O}_{3}-(43-\mathrm{x}) \mathrm{Na}_{2} \mathrm{O}-\mathrm{xPbO}$ $(\mathbf{8} \leq \mathbf{x} \leq \mathbf{3 8}$; mol \%) was investigated. The change in the dissolution rate over time of such glasses shows an improvement in chemical durability with increasing $\mathrm{PbO}$ content to the detriment of $\mathrm{Na}_{2} \mathrm{O}$ content. Both the increase in $\mathrm{PbO}$ content and in the $\mathrm{Pb}+\mathrm{Cr} / \mathrm{P}$ ratio causes an increase in the number of covalent $\mathrm{Pb}-\mathrm{O}-\mathrm{P}$ and $\mathrm{Cr}-\mathrm{O}-\mathrm{P}$ bands, making the glass structure more rigid. IR spectra indicate the formation of short chain pyrophosphates, orthophosphates and probably ring metaphosphates. This radical change in the glass structure led to the formation of crystallites of different sizes. These crystallites seem to play a primary role in the increase in chemical durability of the studied glasses. However, when the crystallites exceed a certain limit, the equilibrium between the glass bath and these crystallites is not longer maintained; we notice, once, a few decrease in the chemical durability. The dissolution rate $\left(D_{R}\right)$ obtained is 50 times less than those of borosilicate glasses, which is used as an alternative method for the vitrification of nuclear waste substances.

\section{References}

[1] Aqdim, S. (1990) Identification et étude thermique et électrique des phasesvitreuses des systèmes ternaires $\mathrm{Li}_{2} \mathrm{O}-\mathrm{M}_{2} \mathrm{O}_{3}-\mathrm{P}_{2} \mathrm{O}_{5}(\mathrm{M}=\mathrm{Cr}, \mathrm{Fe})$. Diplôme D’étudeSupérieure de $3^{\text {ème }}$ Cycle de Spécialité, Faculty of Sciences Rabat. University Mohammed V, Morocco.

[2] Ouchetto, M. (1993) Caractérisation et Approche structural de la région vitreuse du système ternaire $\mathrm{Li}_{2} \mathrm{O}-\mathrm{CdO}-\mathrm{P}_{2} \mathrm{O}_{5}$. Diplôme d'étude de $3^{\text {ème }}$ Cycle Sciences Physiques, Faculty of Sciences Rabat, University Mohammed V, Morocco.

[3] Sales, B.C. and Boatner, L. (1986) Physical and Chemical Characteristics of Lead-Iron Phosphate Nuclear Waste Glasses. Journal of Non-Crystalline Solids, 79, 83-116. http://dx.doi.org/10.1016/0022-3093(86)90040-2

[4] Sales, B.C. and Boatner, L.A. (1984) Lead-Iron Phosphate Glass: A Stable Storage Medium for High-Level Nuclear Waste. Sciences, 226, 45-48. http://dx.doi.org/10.1126/science.226.4670.45

[5] Aqdim, S., Sayouty, E.H. and Elouadi, B. (2008).Structural and Durability Investigation of the Vitreous Part of the System (35-z) $\mathrm{Na}_{2} \mathrm{O}-\mathrm{zFe}_{2} \mathrm{O}_{3}-5 \mathrm{Al}_{2} \mathrm{O}_{3}-60 \mathrm{P}_{2} \mathrm{O}_{5}$. Eurasian Chemico-Technological Journal, 10, 9-17.

[6] Aqdim, S., Elouadi, B. and Grenech, J.M. (2012) Chemical Durability and Structural Approach of the Glass Series (40-y) $\mathrm{Na}_{2} \mathrm{O}-\mathrm{yFe} \mathrm{O}_{3}-5 \mathrm{Al}_{2} \mathrm{O}_{3} 55 \mathrm{P}_{2} \mathrm{O}_{5}$ - by IR, X-Ray Diffraction and Mössbauer Spectroscopy. Material Sciences and Engineering, 27, Article ID: 012003.

[7] Reis, S.T., Karabulut, M. and Day, D.E. (2002) Structural Features of Lead Iron Phosphate Glasses. Journal of NonCrystalline Solids, 304, 188-194. http://dx.doi.org/10.1016/S0022-3093(02)01021-9

[8] Yu, X., Day, D.E., Long, G.J. and Brow, R.K. (1997) Properties and Structure of Sodium-Iron Phosphate Glasses. Journal of Non-Crystalline Solids, 215, 21-31. http://dx.doi.org/10.1016/S0022-3093(97)00022-7

[9] Rais, S.T. and Martinelli, J.R. (1999) Cs Immobilization by Sintered Lead Iron Phosphate Glasses. Journal of NonCrystalline Solids, 247, 241-247. http://dx.doi.org/10.1016/S0022-3093(99)00078-2

[10] Chabbou, Z. and Aqdim, S. (2014) Chemical Durability and Structural Proprieties of the Vitreous Part of the System $\mathrm{xCaO}-(40-\mathrm{x}) \mathrm{ZnO}-15 \mathrm{Na}_{2} \mathrm{O}-45 \mathrm{P}_{2} \mathrm{O}_{5}$. Advances in Materials Physics and Chemistry, 4, 179-180. http://dx.doi.org/10.4236/ampc.2014.410021

[11] Videau, J.J. and Le Flem, G. (2009) Les verres phosphatés de la spécificité de l'atome de phosphore à la formation, la structure et la durabilité chimique de phosphates vitreux. $3^{\text {`eme }}$ Cycle, Université de Bordeaux, France, 66. 
[12] Makhkhas, Y., Aqdim, S. and Sayouty, E.H. (2013) Study of Sodium-Chromium-Iron-Phosphate Glass by XRD, IR, Chemical Durability and SEM. Journal of Materials Science and Chemical Engineering, 1, 1-6. http://dx.doi.org/10.4236/msce.2013.13001

[13] Vast, P. and Semmoud. A. (1994) Comportement Thermique de Difluorodi-Oxophosphate Ferreux. Journal of Thermal Analysis, 41, 1489-1493. http://dx.doi.org/10.1007/BF02549945

[14] Moss, R.M., Abou Neel, E.A., Pickup, D.M., Twyman, H.L., Martin, R.A., Henson, M.D., Barney, E.R., Hannon, A.C., Knowles, J.C. and Newport, R.J. (2010) The Effect of Zinc and Titanium on the Structure of Calcium-Sodium Phosphate Based Glass. Journal of Non-Crystalline Solids, 356, 1319-1324. http://dx.doi.org/10.1016/j.jnoncrysol.2010.03.006

[15] Santic, A., Skoko, Z., Gajovic, A., Reis, S.T., Day, D.E. and Mogus-Milankovic, A. (2011) Physical Properties of Iron Phosphate Glasses Containing $\mathrm{Cr}_{2} \mathrm{O}_{3}$. Journal of Non-Crystalline Solids, 57, 3578-3584. http://dx.doi.org/10.1016/j.jnoncrysol.2011.07.011

[16] Aqdim, S. and Ouchetto, M. (2013) Elaboration and Structural Investigation of Iron (III) Phosphate Glasses. Advances in Materials Physics and Chemistry, 3, 332-339. http://dx.doi.org/10.4236/ampc.2013.38046

[17] Bernado, E., Varasso, M., Cadamuro, F. and Hreglich, S. (2006) Vitrification of Wastes and Preparation of Chemically Stable Sintered Glass-Ceramic Products. Journal of Non-Crystalline Solids, 352, 4017-4023. http://dx.doi.org/10.1016/j.jnoncrysol.2006.07.001

[18] Aqdim, S. and Albizane, A. (2015) Structural Feature and Chemical Durability of Sodium Aluminium Iron Phosphate Glasses. Journal of Environmental Science, Computer Science and Engineering \& Technology, 4, 509-521.

[19] Drabarek, E., McLeod, T.I., Hanna, J.V., Griffith, C.S. and Luca, V. (2009) Tungstate-Based Glass-Ceramics for the Immobilization of Radio Cesium. Journal of Nuclear Materials, 384, 119-129. http://dx.doi.org/10.1016/j.jnucmat.2008.11.018

[20] Santic, A., Mogus-Milankovic, A., Furic, K., Bermanec, V., Kimd, W. and Daye, D.E. (2007) Structural Properties of $\mathrm{Cr}_{2} \mathrm{O}_{3}-\mathrm{Fe}_{2} \mathrm{O}_{3}-\mathrm{P}_{2} \mathrm{O}_{5}$ Glasses, Part I. Journal of Non-Crystalline Solids, 353, 1070-1077. http://dx.doi.org/10.1016/j.jnoncrysol.2006.12.104

\section{Submit or recommend next manuscript to SCIRP and we will provide best service for you:}

Accepting pre-submission inquiries through Email, Facebook, Linkedin, Twitter, etc

A wide selection of journals (inclusive of 9 subjects, more than 200 journals)

Providing a 24-hour high-quality service

User-friendly online submission system

Fair and swift peer-review system

Efficient typesetting and proofreading procedure

Display of the result of downloads and visits, as well as the number of cited articles

Maximum dissemination of your research work

Submit your manuscript at: http://papersubmission.scirp.org/ 